\title{
Use of ethamsylate to reduce postoperative bleeding and transfusion index in total hip arthroplasty. A randomized clinical trial
}

\author{
Uso de etamsilato para reducir el sangrado posoperatorio y el índice de transfusión en la \\ artroplastia total de cadera. Ensayo clínico controlado
}

\author{
Tomás A. Ramos-Sánchez, Tomás Ramos-Morales, Rodolfo Morales-Avalos*, Jaime Blázquez-Saldaña, \\ Víctor M. Peña-Martínez and Félix Vílchez-Cavazos
}

Hip, Lower Limb and Joint Replacement Module, Department of Trauma and Orthopedics, Hospital Universitario Dr. José Eleuterio González, Universidad Autónoma de Nuevo León, Monterrey, N.L. Mexico

\begin{abstract}
Background: Secondary bleeding is one of the leading causes of morbidity after the surgery. Ethamsylate has been used with good results to decrease bleeding in various pathologies such as metrorrhagia, intraventricular bleeding, prostatectomies, cataract surgeries and tonsillectomies. The objective of this study was to evaluate the effectiveness of the hemostatic agent ethamsylate to decrease bleeding in total hip replacement surgery. Method: The population were divided into two groups, in the control group was performed the hemostasis conventionally; in the experimental group ethamsylate was administered. Results: $A$ total of 34 patients were included, of whom 17 were randomized to the group of ethamsylate and 17 randomized to the control group. There were no differences in the characteristics of the population between the two groups. Comparing preoperative hemoglobin levels and at 24, 48 and 72 postsurgical hours between the control group and ethamsylate group there was no statistically significant difference. There was also no difference in the levels of hematocrit. In the quantification of expenditure by the drainage there was no difference between the groups at 24 and 48 hours. There were three patients transfused in the ethamsylate group and seven in the control group, which did not differ significantly $(p=0.62)$. Conclusion: An effect on the reduction of bleeding in patients undergoing total hip replacement with the use of hemostatic agent ethamsylate was not demonstrated in this study.
\end{abstract}

KEY WORDS: Postoperative bleeding. Total hip arthroplasty. Ethamsylate. Transfusion.

\section{Resumen}

Antecedentes: El sangrado secundario es una de las principales causas de morbilidad después de la cirugía. El etamsilato se ha utilizado con buenos resultados para disminuir el sangrado en diversas patologías, como metrorragias, sangrado intraventricular, prostatectomías, cirugías de catarata y amigdalectomías. El objetivo de este estudio fue evaluar la efectividad del etamsilato para disminuir el sangrado en la cirugía de reemplazo total de cadera. Método: La población se dividió en dosgrupos. En el grupo control se realizó la hemostasia de manera convencional; en el grupo experimental se administró etamsilato. Resultados: Se incluyeron 34 pacientes, de los cuales 17 fueron aleatorizados al grupo de etamsilato y 17 al grupo control. No hubo diferencias en las características de la población entre los dos grupos. Al comparar los valores de hemoglobina preoperatoria y a las 24, 48 y 72 horas posquirúrgicas entre ambos grupos, no se encontraron diferencias estadísticamente significativas. Tampoco hubo diferencia en el hematocrito ni en la cuantificación del gasto por drenaje a las 24 y 48 horas. Hubo tres pacientes transfundidos en el grupo de etamsilato y siete en el grupo de control, lo cual no difirió significativamente

\author{
Correspondence: \\ *Rodolfo Morales-Avalos \\ Madrid, 113 \\ Col. Riberas de San Nicolás \\ C.P. 66430 , San Nicolás de los Garza, N.L., México \\ E-mail: rodolfot59@ hotmail.com
}

Date of reception: 23-01-2018

Date of acceptance: 24-04-2018

DOI: 10.24875/CIRUE.M18000041
Cir Cir. 2018;86:240-245

Contents available at PubMed www.cirugiaycirujanos.com 
$(p=0.62)$. Conclusión: En este estudio no se demostró un efecto sobre la reducción de la hemorragia en pacientes sometidos a reemplazo total de cadera con el uso de etamsilato.

PALABRAS CLAVE: Artroplastia total de cadera. Sangrado posoperatorio. Etamsilato. Transfusión.

\section{Introduction}

Total hip replacement, also known as total hip arthroplasty (THA), is an orthopedic surgery intended to replace the hip joint with an orthopedic implant. The main indication for hip arthroplasty remains advanced stage osteoarthritis, when conservative treatment has failed to relieve pain or when pain restricts daily life activities ${ }^{1}$. Avascular necrosis with segmental collapse of the head of the femur and displaced fractures of the neck of the femur in patients older than 60 years have become common indications. THA has been shown to provide a better functional result and fewer complications in comparison with traditional techniques such as internal fixation or hemiarthroplasty for displaced fractures ${ }^{1}$. There are different hip prostheses constituted of an acetabular component and a femoral component. THA is one of the elective procedures that are most commonly practiced in the world. Prevalence has drastically increased in recent years due to an increase in the population life expectancy ${ }^{2}$.

After THA, the bony ends that were sectioned and are exposed when they are not covered by the implants are a factor that significantly contributes to postoperative bleeding $^{3}$. The control of bleeding through exposed bone cannot be achieved with electrocautery or by vessel ligation ${ }^{4}$. In addition, the use of antiplatelet agents and anticoagulants to reduce thromboembolic incidents increases bleeding complications. Perioperative THA-associated blood loss is one of the main causes of postoperative morbidity, including pain, decreased range of motion and increased requirements for allogeneic transfusions, which can result in substantial increases in costs and significant complications, such as postoperative infection, delayed patient recovery, prolonged hospital stays and increased mortality ${ }^{5}$. Perioperative blood loss in primary total hip replacement surgery has been reported to be as high as 1 to 2 liters $^{6}$, which is equivalent to $4 \pm 1.5 \mathrm{~g} / \mathrm{dL}$ of hemoglobin. Owing to this, postoperative anemia in patients undergoing THA can occur in up to $87 \pm 10 \%{ }^{7}$. The high reported incidence of postoperative anemia entails a higher rate of transfusion in these patients, which reportedly can be as high as $26 \%$, depending on the experience of the center where this procedure is performed. In the USA, 24 million blood components are administered annually ${ }^{3,8}$. In the area of orthopedics, $10 \%$ of all transfused red blood cell units are used, out of which $39 \%$ are used in hip and knee arthroplasties ${ }^{9}$. In England, hip and knee arthroplasties consume $8 \%$ of all transfused blood product units ${ }^{10}$. Allogeneic transfusions have been the standard method for the management of anemia due to acute blood loss secondary to THA. However, despite very strict management protocols, allogeneic transfusions carry significant inherent risks, including viral transmission, $A B O$ group incompatibility and hemolysis, among others ${ }^{11,12}$.

Although there is a large number of strategies for the management of perioperative bleeding, there is scant literature available to support their use. Owing to the potential complications and adverse events that are associated with blood loss and allogeneic blood transfusions ${ }^{2}$, it is imperative to explore new preservation and management strategies to reduce perioperative bleeding.

Ethamsylate has been used as a hemostatic agent for more than 40 years in intraventricular bleeding in premature patients and in abnormal uterine bleeding. It has also been used to reduce transoperative bleeding in adenoidectomies, prostatectomies, cataract surgeries, and maxillofacial and dental surgeries ${ }^{13}$. In the latest studies about its mechanism of action, ethamsylate has been found to promote leukocyte and platelet aggregation when blood is in contact with any damaged vascular segment, and thus there is little risk of thromboembolic adverse events ${ }^{14}$. The mechanisms by means of which it promotes leukocyte and platelet aggregation known to date are two. The first that was demonstrated is that it increases P-selectin expression in platelet membranes, which promotes platelet aggregation ${ }^{15}$. The other mechanism is P-selectin glycoprotein ligand 1 (PSGL-1) increased expression on the leukocyte membrane, which promotes the formation of leukocyte and platelet aggregates ${ }^{14}$. There is little experience in the use of ethamsylate in orthopedic surgeries and, therefore, the purpose of the present study is to determine its efficacy as a hemostatic agent in THA surgeries in comparison with placebo.

\section{Method}

A controlled clinical trial with a randomized, comparative, prospective and experimental design was carried out. 


\section{Study population}

Using a hypothesis testing formula and a difference of two means, with a $z \alpha$-value of 1.96 and a two-tailed $95 \%$ level of significance, and a $z \beta$-value of 0.84 with a power of $80 \%$, a sample of 17 participants per group was obtained. The inclusion criteria were: people older than 30 years who underwent primary total hip replacement surgery due to osteoarthrosis, avascular hip necrosis or transcervical hip fracture. All participants were asked to sign an informed consent expressing their wish to participate in the study. The exclusion criteria were applied to participants with blood dyscrasias, cognitive deficit, allergy to ethamsylate or thrombotic events within the previous 6 months.

\section{Patient selection and randomization}

Patient randomization to the treatment and control groups was performed using a table system that can be found on the website www.randomization.com. Patients assigned to the experimental group were administered ethamsylate, while those who were included in the control group did not receive any medication.

\section{Total hip replacement procedure and medication administration}

The surgeries were performed with the patient in lateral decubitus and under epidural block-type anesthesia and sedation. Suturing was carried out in planes, with reinsertion of the anterior portion of the gluteus medius muscle being performed. Closure of the fascia lata was performed and a 1/4 inch Drenovac $^{\oplus}$-type drainage was placed above it and beneath the subcutaneous cellular tissue, which was left with suction after 4 hours of clamping. The subcutaneous cellular tissue was sutured in the usual manner and the skin was closed with staples. At the end, a patch with gauze and Hypafix ${ }^{\circledR}$ was placed. In all patients, traditional measures were used to prevent bleeding, such as the use of electrocautery (Valleylab Force EZ) and application of direct pressure on bleeding points.

The medication was kept at room temperature, at no more than $25^{\circ} \mathrm{C}$, and protected from light. $500 \mathrm{mg}$ (two 250 mg-ampoules. undiluted, slowly administered) of ethamsylate (Dicynone ${ }^{\circledR}$ ) were intravenously applied within the 30 minutes prior to the surgical procedure and $500 \mathrm{mg}$ were applied at the moment of femoral neck osteotomy. All patients were managed with subcutaneous low molecular weight heparin within the first 2 postoperative days, and subsequently were switched to oral activated factor $\mathrm{X}$ inhibitor for another 30 days for venous thromboembolism prophylaxis. All patients started physical therapy with exercises within the first 24 hours and all were mobilized within the first 48 hours.

\section{Assessment of the obtained results: hemoglobin, hematocrit, drainage quantification and transfusion rate}

Patient general data were obtained: age, gender, weight, height, body mass index and personal history. Hemoglobin and hematocrit were preoperatively measured and at $06: 00 \mathrm{~h}$ of postoperative days 1,2 and 3 . The drainage output was quantified at 24 and 48 hours postoperatively, and then it was withdrawn. The transfusion rate was measured according to the designated hemoglobin value. Finally, the functional scale (visual analogue scale) was evaluated at 24, 48 and 72 hours (Table 1). In the postoperative period, all patients with hemoglobin values $<9 \mathrm{mg} / \mathrm{dL}$ with anemia were transfused.

\section{Results}

Thirty-four patients were included, out of which 17 were randomized to the ethamsylate group and 17 to the control group. Population characteristics of each study group (age, gender and diagnosis) were analyzed, without differences being found between both groups. Mean age in the control group was $60.90 \pm$ 13.01 years, and in the ethamsylate group it was 58.57 \pm 13.44 years, with no statistically significant difference $(p=0.67)$. As for gender, there was no statistically significant difference between the control and the ethamsylate groups $(p=0.82)$ (Table 2).

The included diagnoses were femoral fracture, coxarthrosis and avascular necrosis of the hip. In the control group, seven patients (41.18\%) had transcervical hip fracture, seven (41.18\%) had coxarthrosis and three (17.64\%) had avascular necrosis of the hip. In the ethamsylate group, five patients with transcervical hip fracture $(29.41 \%)$, seven with coxarthrosis $(41.18 \%)$ and five with avascular hip necrosis $(29.41 \%)$ were operated; there were no statistically significant differences $(p=0.81)$.

Hemoglobin value measurements were performed prior to surgery and on postoperative days 1,2 and 3 . A preoperative value of $13.54 \pm 1.17 \mathrm{~g} / \mathrm{dL}$ was found 
Table 1. Assessed variables and assessment time points

\begin{tabular}{lllll}
\hline Variable & Preoperatively & Postoperative day $\mathbf{1}$ & Postoperative day 2 & Postoperative day 3 \\
\hline Hemoglobin & 1 collection & 1 collection 06:00 h & 1 collection 06:00 h & 1 collection 06:00 h \\
Hematocrit & 1 collection & 1 collection 06:00 h & 1 collection 06:00 h & 1 collection 06:00 h \\
Drainage output & & $24 \mathrm{~h}$ post-surgery & $48 \mathrm{~h}$ post-surgery & \\
Visual analogue scale & 1 measurement & 1 measurement & 1 measurement & 1 measurement \\
\hline
\end{tabular}

Table 2. Demographic characteristics of the population included in the study

\begin{tabular}{lccc}
\hline Characteristics & Control & Ethamsylate & $\mathbf{p}$ \\
\hline Age & $60.90( \pm 13.01)$ & $58.57( \pm 13.44)$ & 0.67 \\
Males & $\mathrm{n}=7(41.18 \%)$ & $\mathrm{n}=8(47.06 \%)$ & 0.82 \\
Females & $\mathrm{n}=10(58.82 \%)$ & $\mathrm{n}=9(52.94 \%)$ & \\
\hline
\end{tabular}

in the control group, whereas in the ethamsylate group it was $13.60 \pm 1.41 \mathrm{~g} / \mathrm{dL}(\mathrm{p}=0.9)$. On day 1 post-surgery, a hemoglobin value of $9.69 \pm 0.95 \mathrm{~g} / \mathrm{dL}$ and $10.15 \pm 1.82 \mathrm{~g} / \mathrm{dL}$ was found for the control group and the ethamsylate group, respectively $(p=0.48)$. On postoperative day 2 , the values found in the control and the ethamsylate groups were $9.26 \pm 1.25 \mathrm{~g} / \mathrm{dL}$ and $9.46 \pm 1.53 \mathrm{~g} / \mathrm{dL}$, respectively $(p=0.74)$. Finally, on postoperative day 3 , values of $8.99 \pm 1.42 \mathrm{~g} / \mathrm{dL}$ were found in the control group and $9.01 \pm 1.06 \mathrm{~g} / \mathrm{dL}$ in the ethamsylate group $(p=0.97)$. Although hemoglobin values were lower in the control group, the difference was not statistically significant (Fig. 1).

Hematocrit was also assessed prior to surgery and on postoperative days 1, 2 and 3 . Initially, hematocrit was $41.98 \pm 3.53 \%$ in the control group and $41.42 \pm$ $4.43 \%$ in the ethamsylate group $(p=0.74)$. On the first postoperative day, hematocrit in the control group and in the ethamsylate group was $29.44 \pm 3.18 \%$ and $30.76 \pm 5.80 \%$, respectively $(p=0.52)$. On the second postoperative day, hematocrit in the control group was $28.0 \pm 4.12 \%$ and $28.49 \pm 4.53 \%$ in the ethamsylate group ( $p=0.78$ ). The last day, hematocrit was 27.16 $\pm 4.54 \%$ in the control group and $26.11 \pm 5.91 \%$ in the ethamsylate group $(p=0.65)$. Although a tendency towards lower hematocrit was found in the control group on postoperative days 1 and 2, the difference was not statistically significant (Fig. 2).

Drainage output was quantified at 24 and 48 hours post-surgery (Fig. 3). In the measurement performed at 24 hours, output was lower in the control group than in the ethamsylate group, with $171.33 \pm 166.91 \mathrm{~mL}$ and $209.57 \pm 179.14 \mathrm{~mL}$, respectively, without the difference being statistically significant $(p=0.61)$. In contrast, drainage output at 48 hours was found to be higher in the control group than in the etamsylate group, with $174.44 \pm 137.87 \mathrm{~mL}$ and $144.85 \pm$ $135.07 \mathrm{~mL}$, respectively, without the difference being statistically significant $(p=0.61)$

The transfusion rate was measured in both the control and the ethamsylate groups, with seven patients being found to have been transfused in the control group and three in the ethamsylate group, with the difference not being statistically significant $(p=0.62)$. The indications for transfusion in all cases were hemoglobin values $<9 \mathrm{mg} / \mathrm{dL}$ together with data consistent with anemia (dizziness, diaphoresis, tachycardia, etc.). In nine of the ten cases, only one red cell unit was transfused, and in one case, transfusing two units was necessary.

During the evaluation period, no perioperative or postoperative complications were reported in the included patients (except for the need for transfusion). There was no significant difference in the visual analogue scale results (Table 3 ).

\section{Discussion}

The use of etamsylate as a treatment to reduce bleeding has shown its efficacy in various pathologies and non-orthopedic surgical procedures, with a low rate of adverse effects ${ }^{11}$. However, there is not much evidence of its efficacy in orthopedic surgeries. In the literature, only one article assessing ethamsylate efficacy in orthopedic surgeries was found, where a similar dose of the drug was used prior to anesthetic induction ${ }^{16}$. As in our study, ethamsylate was not found to have a positive effect on bleeding reduction in total hip replacement surgery. In this study, the fact that this type of procedure implies larger trauma to the tissues in comparison with other surgeries where a decrease in bleeding has been demonstrated was proposed as a possible explanation for the lack of efficacy.

No differences were found in both groups population's characteristics. The hemoglobin and hematocrit values found in our study were higher in the ethamsylate group 


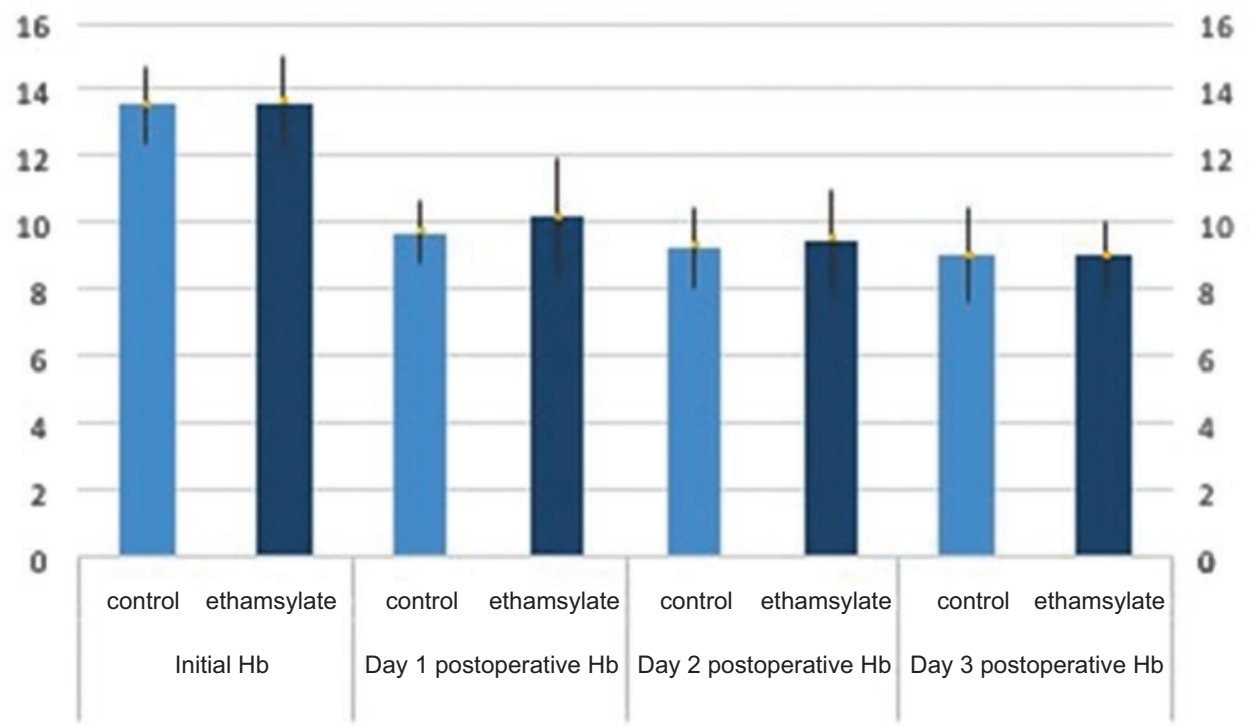

Figure 1. Means and standard deviations of hemoglobin values obtained for each group on the different assessment days. Hb: hemoglobin.

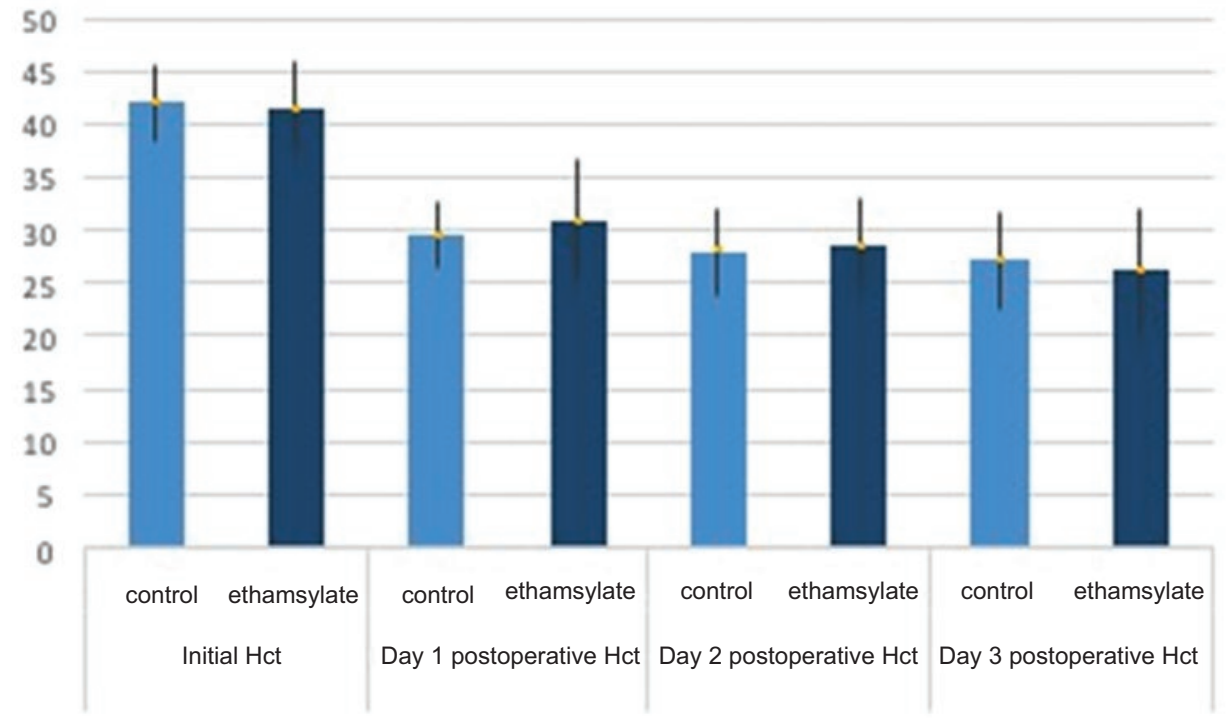

Figure 2. Means and standard deviations of hematocrit values obtained for each group on the different assessment days. Hct: hematocrit.

Table 3. Preoperative analogue visual scale and on postoperative days 1,2 and 3

\begin{tabular}{lccc}
\hline Characteristics & Control & Ethamsylate & $\mathbf{p}$ \\
\hline Preoperative VAS & $6.1( \pm 3.02)$ & $6.3( \pm 2.6)$ & 0.86 \\
Postoperative day 1 VAS & $3.5( \pm 2.07)$ & $3.6( \pm 2.2)$ & 0.94 \\
Postoperative day 2 VAS & $2.1( \pm 1.9)$ & $2.7( \pm 1.5)$ & 0.42 \\
Postoperative day 3 VAS & $1.7( \pm 1.7)$ & $1.5( \pm 2.6)$ & 0.85 \\
\hline VAS: visual analogue scale. & & &
\end{tabular}

than in the control group, but the difference did not reach statistical significance as to demonstrate its efficacy. When the hemoglobin values reported in this article were compared with the postsurgical hemoglobin values in the control group of other studies, we found similar results.

Something that may have influenced on the results of this study is that, owing to an unexpected decrease in the number of eligible patients for total hip replacement in our institution, various pathologies were included, such as post-traumatic osteoarthritis, hip fractures and rheumatoid arthritis, which have a higher tendency to bleed and sometimes have scar tissue and fibrous tissue, which translates into greater manipulation of tissues and longer surgical time, which in turn is associated with more bleeding. This should be acknowledged as a limitation of the study that might be a source of biases. 


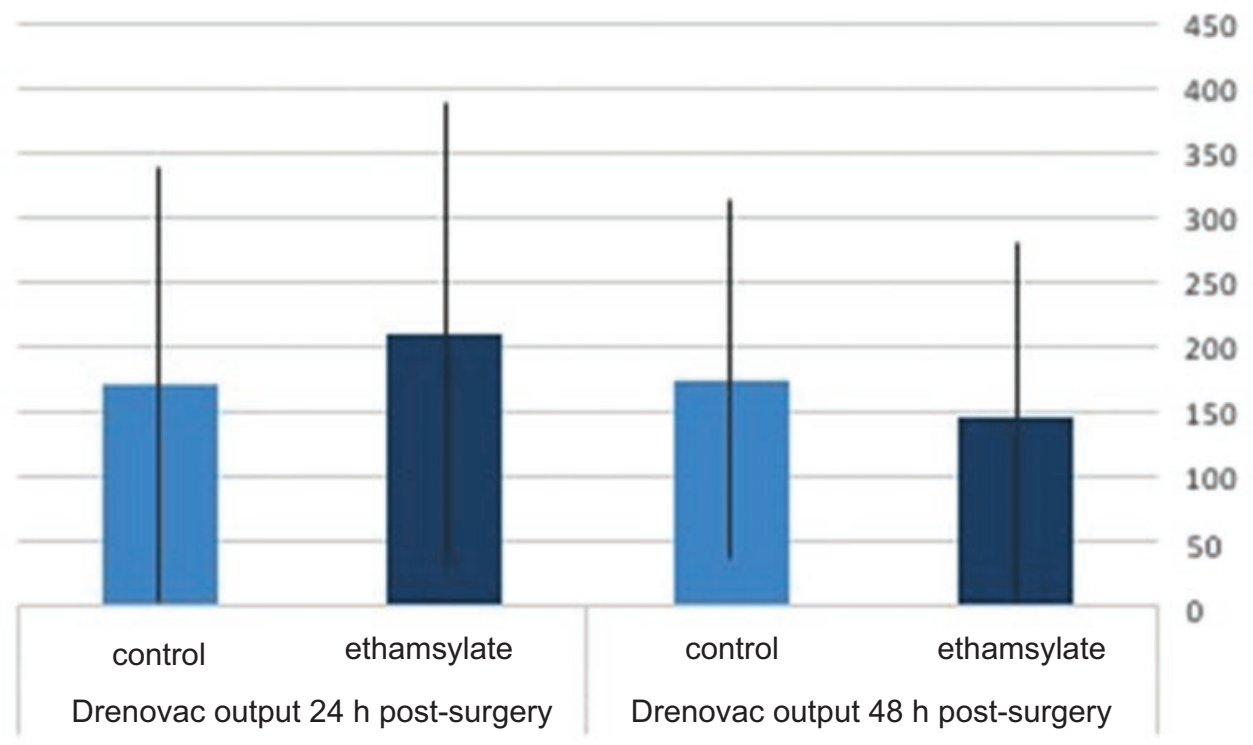

Figure 3. Drainage output means and standard deviations for each group on the different evaluation time-points.

With the performance of this study, the broad safety margin of this drug could be verified, since there were no adverse events in any of the patients it was administered to. Ethamsylate is a medication that can continue to be administered every 6 hours while there is bleeding risk; we do not know if continuing the medication during this period would have resulted in any significant difference, and further studies may therefore be necessary to completely rule out the efficacy of this drug.

Although there was no difference in the transfusion rate between both groups, overall transfusion rate was $33.3 \%$, similar to that described in the literature, which is why the search for a safe, efficacious and accessible drug to reduce the rate of THA-associated complications should be continued.

\section{Conclusions}

No statistically significant difference was found in any of the assessed parameters (hemoglobin, hematocrit, transfusions and drainage output quantification).

The performance of new studies with larger numbers of patients, better control in inclusion diagnoses and considering longer administration of the medication is required in order to completely rule out its efficacy.

\section{Conflicts of interest}

The authors declare not having any conflicts of interest.

\section{References}

1. Bucholz RW. Indicaciones, técnicas y resultados de reemplazo total de cadera en Estados Unidos. Rev Med Clin Condes. 2014;25:760-4.

2. Levine BR, Haughom B, Strong B, Hellman M, Frank RM. Blood management strategies for total knee arthroplasty. J Am Acada Orthop Surg. 2014;22:361-71.

3. Ponnunsamy KE, Thomas TJ, Khnuja HS. Perioperative blood transfusions in orthopaedic surgery. J Bone Joint Surg Am. 2014;96:1836-44.

4. Raut W, Stone MH, Wroblewski BM. Reduction of postoperative blood loss after press-fit condylar knee arthroplasty with use of a femoral intramedullary plug. J Bone Joint Surg Am. 1993;75:1356-7.

5. Sáhn DR. Anemia and patient blood management in hip and knee surgery: a systematic review of the literature. Anesthesiology. 2010;113: 482-95.

6. Bierbaum BE, Callaghan JJ, Galante JO, Rubash HE, Tooms RE, Welch RB. An analysis of blood management in patients having a total hip and knee arthroplasty. J Bone Joint Surg Am. 1999;81:2-10.

7. Spahn DR. Anemia and patient blood management in hip and knee surgery: a systematic review of the literature. Anesthesiology. 2010; 113:482-95.

8. Goodnough LT, Levy JH, Murphy MF. Concepts of blood transfusion in adults. Lancet. 2013;381:1845-54.

9. Young SW, Marsh DJ, Akhavani MA, Walker CG, Skinner JA. Attitudes to blood transfusion post arthroplasty surgery in the United Kingdom: a national survey. Int Orthop. 2008;32:325-9.

10. Wells AW, Mounter PJ, Chapman CE, Stainsby D, Wallis JP. Where does blood go? Prospective observational study of red cell transfusion in north England. BMJ. 2002;325:803

11. Kirkley SA, Cowles J, Pellegrini VD, Harris CM, Boyd AD, Blumberg N. Blood transfusion and total joint replacement surgery: T helper $2(\mathrm{TH} 2)$ cytokine secretion and clinical outcome. Transfus Med. 1998;8:195-204.

12. Klein HG. How safe is blood, really? Biologicals. 2010;38:100-4.

13. Garay RP, Chiavaroli C, Hannaert P. Therapeutic efficacy and mechanism of action of ethamsylate, a long-standing hemostatic agent. Am J Ther. 2006;13:236-47.

14. Hernández MR, Álvarez-Guerra M, Escolar G, Chiavaroli C, Hannaert P, Garay RP. The hemostatic agent ethamsylate promotes platelet/leukocyte aggregate formation in a model of vascular injury. Fundam Clin Pharmacol. 2004;18:423-30.

15. Álvarez-Guerra M, Hernández MR, Escolar G, Chiavarolic C, Garaya RP, Hannaer P. The hemostatic agent ethamsylate enhances P-selectin membrane expression in human platelets and cultured endothelial cells. Thromb Res. 2002;107:329-35.

16. Keith MB. Ethamsylate and blood loss in total hip replacement. Anaesthesia. 1979;34:666-70. 